\title{
Genç Lider Yöneticilerin İnovasyon Anlayışı: Turizm Sektörü Üzerine Bir Alan Araştırması
}

\author{
DOI: $10.26466 /$ opus.396335 \\ * \\ Murat Türk* - Ergün Kara**
}

* Prof. Dr., Osmaniye Korkut Ata Üniversitesi, İ.İ.B.F.Yönetim Biliş. Sist. Böl., Osmaniye/Türkiye E-Posta: muratturk@osmaniye.edu.tr

ORCID: 0000-0001-7040-4180

* Dr. Öğr. Ü., Osmaniye Korkut Ata Üniversitesi, İ.̇̇.B.F. İşletme Bölümü, Osmaniye/Türkiye

E-Posta: ergunkara@osmaniye.edu.tr

ORCID: $\underline{0000-0002-7815-1111}$

\section{Öz}

Bu çalışmanın temel amacl, turizm sektöründe çalışan genç lider yöneticilerin yenilikçi bakış açısının ne durumda olduğunu araştırmak ve söz konusu işletmelerin tüm birimlerinde yönetici konumunda çalışan orta ve üst düzey genç personelin inovasyon anlayışı üzerine bir araştırma yapılmasıdır. Bir hizmet endüstrisi olan ve turizm sektöründe faaliyet gösteren turizm işletmeleri, sektördeki varlıklarını sürdürebilmek ve rekabet güçlerini arttırmak için maliyetlerini en aza indirme, yeni ürün ve hizmetlerle çeşitliliği ve kaliteyi arttırma yoluna gitmektedirler. Sektördeki yeni pazarlara hitap etmek ve pazar payın arttırmak isteyen turizm işletmelerindeki genç lider yöneticiler, inovasyona ihtiyaç duymakta, büyüme ve gelişme için inovasyonu önemli bir unsur olarak görmektedirler. Dolayısıyla turistik ürün ve hizmet sunan turizm işletmeleri için inovasyon önemli hale gelmekte ve ayrıca turistik tüketicileri memnun etme, ihtiyaçların dikkate alma, daha çok turist çekebilme ve rekabetin yoğun olduğu sektörlerden biri olarak varlğ̆ını sürdürmek için turistik ürün ve hizmetlerde yenilik, farklılık ve iyileştirme yapmaktadırlar. Yapılan araştırmayla bu sorunların ortaya çıkarılması ve analiz edilmesi amaçlanarak söz konusu işletmelere ve literatüre katkı sağlaması düşünülmektedir. Çalışma, konu ile ilgili kaynakların taranması yöntemi ve teorik saha araştırmalarına dayanmaktadır.

Anahtar Kelimeler: Genç Yönetici, İnovasyon, Turizm Sektörü 


\title{
Innovation Porspective of Young Leadership Managers: A Field Survey On Tourism Sector
}

\begin{abstract}
The main purpose of this The main purpose of this study is to research at what position the innovation prospective of young leader managers working in tourism sector and on the perception innovation of middle and high grade young staffworking in the management position in all departments in the managements in question. Tourism managements which are service industry and acting in tourism direct their ways to increase quality and variety through new products, services and decrease their costs to survive in the sector and increase their competitive powers. Young leader managers requesting to increase their market rate and appeal to new markets in the sector need innovation, accept it as an important factor for expansion and development. Therefore, innovation gains importance for tourism managements presenting touristic product and service, they make innovation, difference and upgrade in touristic products and service in order to survive as one of the sectors which has intense competition to attract more tourists, consider their needs, satisfy touristic consumers. It is purposed that making contribution to both literature and managements in question to be revealed these problems and analyzed them. This work is based on theoretical field researches and scanning related sources technique about the topic.
\end{abstract}

Keywords: Young Manager, Innovation, Tourism Sector

OPUS @ C Uluslararası Toplum Araştırmaları Dergisi-International Journal of Society Researches ISSN:2528-9527 E-ISSN : 2528-9535

http://opusjournal.net 


\section{Giriş}

Liderlik ve yöneticilik konuları, geçmişten bugüne kadar yazarlar ve araştırmacılar tarafından çok yönlü araştırılmış ve üzerinde durulmuştur. Son yıllarda yaşanan formel organizasyon yapılarının bozulması, bilgi ve iletişimin artan önemi, yoğun rekabet ortami, projelerin uygulanmasında ekipleşmenin önemi, ürün çeşitliliğini getirdiği müşteri beklentilerindeki artış, ekonomik krizlerin sık sık tekrarlanması gibi sebeplerden dolayı örgütlerde lidelik önemli bir unsurhaline gelmiştir Liderliğin önemli olduğu ve vazgeçilmez bir hale geldiği alanlardan biri, belki de en önemlisi ise işletmecilik ve yönetim alanıdır. Günümüzde özellikle iyi eğitim almış girişimci genç liderlerin, işletmelerdeki inovatif yönetim anlayışı ve tarzı, işletme geleceği açısından önemli görülmektedir (Taşkıran, 2006).

Hiç şüphesiz inovasyona en açık sektörlerden birisi de turizmdir. Küreselleşen dünyanın en önemli ve en büyük ekonomik faaliyetlerinden birisi olan turizm endüstrisi, bir çok ülkenin ekonomik gelişiminin itici gücünü oluşturmaktadır. Ayrıca turizm sadece ekonomik olarak değil, toplumları sosyal ve kültürel açıdan bir birine kaynaştıran, dünya barışına katkı yapan bir sektördür. Dünya Seyahat ve Turizm Konseyi verilerine göre, turizm sektörünün küresel ölçekte 5.474 milyar dolarlık bir hacme (dünya GSYH'sının \%9,4'ü) sahip olduğu tahmin edilmektedir (KUDAK, 2011).

Turizmde çalışanlar ve müşterilerin yakın etkileşim içerisinde bulunması, ürünlerin ve müşterilerine sunumunun bir bütün olması, aynı mekan ve zaman içerisinde tüketilmesi nedeniyle, müşteri memnuniyetinin önemi diğer bir çok sektöre nazaran turizm sektöründe çok daha önemlidir. Dolayısıyla bütün sektörler için geçerli olan bu rekabet koşullarındaki hızlı değişimlere ayak uyduracak turizmde nitelikli yönetici ve liderlerin önemi giderek artmaktadır. Geçmişte işletmelerin rekabette öne geçmelerini sağlayan fark yaratmak ve yenilikçi olmak, artık işletmelerin yaşamlarına devam edebilmeleri için gerekli şart haline gelmiştir (Akın ve Sezerel, 2015).

Turizm endüstrisindeki çeşitlenme ile birlikte dünyada giderek artan rekabet, bu sektörde faaliyet gösteren işletmeleri daha farklı ürün ve hizmetler ortaya koymaya zorlamaktadır. Ancak turizm rekabetinde sıklıkla başvurulan ve tüketici tercihini doğrudan etkileyen kaliteli hizmet düşük 
fiyatlandırma anlayışı işletmelerin gelir gider dengesinde ve örgüt yapısında bozulmaya, istihdam politikalarında istikrarsızlığa neden olmaktadır. Bu yüzden rekabetin kaçınılmaz olduğu turizm sektöründe işletmelerin mali ve fiziki yapısını koruması, rakiplerinin önüne geçmesi ve çevreye uyumunu sağlayacak inovasyon faaliyetleri için modern yönetim anlayışına sahip genç liderlere ihtiyaç duyulmaktadır. Bu çalışma ile turizm sektöründe görev yapan genç yöeticilerin inovasyon algısı ve uygulamalarına yönelik literatür taraması yapılması, sonuçlarının teorik olarak çok boyutlu analiz edilmesi, yorumlanması ve literatüre katkı yapılması düşünülmektedir.

Yukarda anlatılanlar ışığında bu makalenin amacı, turizm sektöründe çalışan genç lider yöneticilerin yenilikçi bakış açısının ne durumda olduğunu araştırmak ve söz konusu işletmelerin tüm birimlerinde yönetici konumunda çalışan orta ve üst düzey genç yöneticilerin inovasyon anlayışı üzerine bir araştırma yapılmasıdır. Ayrıca bu araştırma ile turizm işletmelerinde kullanılan liderlik ekseninde inovasyonun ve yönetiminin, işletmeler üzerindeki etkileri ile ne şekilde gerçekleştiğinin saptanması amaçlanmıştır.

Araştırmanın kapsamı turizm sektöründe faaliyet gösteren işletmelerdeki yönetici konumunda çalışan orta ve üst düzey genç yöneticilerin ve diğer departman birimlerin de çalışan kısım amirlerini kapsamaktadır. Araştırmada incelenen sorun daha önce turizm işletmelerindeki orta ve üst düzey yöneticilerle birebir konuşularak Ar-Ge, inovasyon ve yönetimde liderlik konularına yönelik sorunlar sözlü olarak tartışılmıştır.

Literatürde genç lider yöneticilerin inovasyon anlayışına yönelik olarak yapılan çalışmalar incelendiğinde bu çalışmaların kısıtlı sayıda olduğu görülmektedir. Bu araştırmalarddan bazıları aşağıda belirtilmiştir.

Coşkun, vd.,(2013), Kocaeli'nde bulunan Turizm İşletme Belgesine sahip, yıldızlı konaklama tesislerinde uygulanan inovasyon stratejilerinin stratejik rekabet üstünlüğü sağlamada etkili olup olmadığını belirlemek üzerine bir araştırma yapmışlardır. Yapılan bu araştırma sonucunda, otel işletmeleri inovasyon faaliyetlerini uygulamakta olduğu tespit edilmiştir. Ayrıca, konaklama işletmelerinin genel olarak artımsal inovasyon boyutu içerisinde ürün, hizmet ve süreç inovasyonları uyguladıkları, maliyet liderliği, farklılaştırma ve odaklanma stratejileri ile saldırgan ve fırsatları 
izleyen inovasyon stratejisi arasında olumlu bir ilişki olduğu sonucu belirlenmiştir.

Taşgit, E.,S, ve Torun, B. (2016), Düzce ilinde faaliyet gösteren KOBİlerin üst düzey (sahip) yöneticilerinin inovasyon algıları, inovasyon sürecini yönetme tarzları ve işletmenin inovasyon performansı arasındaki ilişkileri ve etkileşimleri incelemek amaçlı bir araştırma gerçekleştirmişlerdir. Yapılan çalışma sonucunda Dönüşümcü tarzda yönetme üzerinde en yüksek pozitif etkiye sahip olan değişkenin "Kalite artışı", Karizmatik tarzda yönetme ve Hizmetkâr tarzda yönetme üzerinde en yüksek pozitif etkiye sahip olan değişken "Krizden Çıkış" ve Stratejik tarzda yönetme üzerinde en yüksek pozitif etkiye sahip olan değişken "Rekabet Avantajı" olduğu ayrıca ek maliyet algısı tüm yönetim tarzları üzerinde negatif etkiye sahip olduğu sonucuna ulaşmışlardır.

Literatürde bakıldığında genç lider yöneticilerin inovasyon anlayışını etkileyen bir çok dinamik mevcuttur. Turizm sektöründeki artan rekabet ve hizmet çeşitliliğine paralel olarak, genç lider yöneticilerin geliştirdikleri karar kriterlerinin doğru analiz edilmesi ve turizm sektöründeki güncel dinamiklerin takip edilmesi hem işletmeler açısından hem de yöneticiler açısından büyük önem kazanmıştır.

\section{Liderlik}

Kavram olarak liderlik yüzyıllar öncesinden kullanılmaya başlanılmış olsa da endüstri devrimi sonrasında örgüt yapılarında önem kazanmaya başlamıştır. 1950'li yıllardan sonra dünyada hızla gelişmeye başlayan teknolojinin ortaya çıkardığı ekonomik ve sosyal alanlardaki yeni akımlarla birlikte liderliğin çeşitli tanımları yapılmaya başlanmıştır. Bir tanımda liderlik, gerekli şartların sağlandığı durumlarda örgütsel hedeflere veya işletmeyle birlikte çalışanların da ortak çıkarlarına ulaşması için çalışanların, işletmen iç ve dış dinamikleri ile fiziki ve finansal yapısını deneyimlere dayanılarak koordineli bir şekilde sevk, idare ve yönetilmesi süreci olarak tarif edilebilir (Werner, 1993).

Yine diğer bir tanıma göre liderlik, organizasyonların bütünü kapsayacak şekilde başarıyı yakalaması için gerekli olan yönetimde dürüstlük, çalışanların kişilik ve çalışma haklarına saygı duymak ve organizasyonu en uygun şekilde yönetmek ilkelerine bağlı kalınarak 
amaçlara ulaşmada motivasyon esaslı çalışma olarak tanımlanmıştır. Liderlik vasfına sahip kişiler, davranış ve eylemleri ile lideri olduğu örgüttekileri güven duygusu içerisinde peşlerinden sürüklerler. Takipçilerinin lideri isteyerek ve severek izlemeleri için güven duygusunun oluşması oldukça önemli bir konudur. İyi bir liderlik için karizma sahibi olmak, alçakgönüllü davranmak, fedakar olmak, her türlü şartta ilke ve hedeflerinden ayrılmamak ve motivasyon odaklı çalışmak temel şartlardır. Liderlikte dürüstlüğ̈̈n önemine vurgu yapan Drucker, dürüst olmayan liderlerin başarıyı yakalamasının imkansız olduğunu belirtmiştir (Cohen,2010).

Tanımlardan da anlaşılacağı üzere liderlik sürecinde ortak amaçlar, liderin yapısı, onu izleyenler ile ortam şartları bütün olarak önem taşımaktadır. Liderin izleyicileri yönetimsel olarak sahip olduğu güçle baskı altına alarak amaçlarına ulaşması mümkün değildir. Bu nedenle lider, onlara güven aşılayarak desteklerini almak suretiyle eylemlerini gerçekleştiren kişidir. Ayrıca lider sadece kendi becerilerini sonucu olarak ortaya çıkmaz, grup üyelerinin de lideri sahiplenmesi ve benimsemesi gerekmektedir (Şimşek ve Çelik, 2011).

Liderlik konusu, günümüze kadar yönetim alanında uzman birçok düşünür tarafından araştırılmış, incelenmiş ve sonuç olarakta ortaya birçok liderlik teorileri atılmıştır. Lidelik konusunun bu kadar çok araştırlmasının asıl sebebi, iş dünyasında rekabetle başa çıkılabilmesi, avantaj sağlanması, gelişim ve değişim süreçlerinde liderliğin temel unsur olarak görülmesidir. Uzmanlar liderlik teorilerini; liderlerin özelliklerine, davranışlarına, durumsallığına ve yeni yönetim teknikleri uygulamalarına göre ayırmışlardır (İbicioğlu vd., 2009).

Liderlerin sahip olması gerektiği birtakım özellikler vardır. Bu özellikler başarılı bir lider olmak için gerekli olup, bütün lider tipleri içinde ortak paydayı oluşturmaktadır. Liderde bulunması gereken özellikleri sıralayacak olursak (Şahin vd., 2004):

$\checkmark$ Her şeyden önce iyi bir lider, kendisini çok iyi tanımalı ve karşı tarafla etkileşimi bilmelidir.

$\checkmark$ Yaptığı işte uzmanlaşmış olmalı ve faaliytlerinde gerçekleştirilmesinde en basit yöntemleri seçmelidir. 
$\checkmark$ Hitap edeceği grup üyelerini veya takipçilerini iyi etüt etmeli ve onlara güvenmelidir.

$\checkmark$ Ulaşmak istediği amaçları, hedefleri ve standartları önceden belirlemelidir.

$\checkmark$ Kararlarını hedef odaklı olarak en hızlı şekilde almalıdır.

$\checkmark$ Diğer çalışanların, grup üyelerinin kararlara katmasını sağlamalı, farklı görüşlere saygı duyarak demokratik davranmalıdir.

$\checkmark \quad$ İyi bir lider geleceği görebilen, tehlikeleri önceden süzen ve bunlara yönelik akılcı planlar geliştirebilmelidir.

$\checkmark$ İnandığı hedefler doğrultusunda ödün vermeden, amaçlarını gerçekleştirmek için sabırlı ve kararlı davranmalıdır.

$\checkmark$ Zorlu koşullarda bile inancını kaybetmemeli, umusuzluğa kapılmamalı ve çevresindekilere örnek olarak onların motivasyonunu yüksek tutmalıdır.

$\checkmark$ Özgün çalışma şekline sahip, araştırmacı ve olasılıkzorlamaktan çekinmeyen bir yapıda olmalıdır.

$\checkmark$ Herkesin güven duyabileceği, kolayca ulaşabileceği ve alçak gönüllü olmalıdır.

$\checkmark$ Gerektiğinde risk almaktan çekinmeyen, takipçileri üzerinde baskıcı olmayan ve zamanı iyi planlayıp iyi yönetmelidir.

$\checkmark$ Eleştiriye her azman açık olmalı ve sonuçları sürekli takip etmelidir.

Artık günümüzdeki büyük işletmeler küreselleşmenin bir sonucu olarak dünya ticaretine açılmışlardır. Önceden sadece ulusal bir pazar yapısı ve onun getirdiği rekabet şartları varken, teknolojik gelişmelerin hızlanması, kartel oluşturan şirketlerin varlığ 1 ve diğer değişen koşullar nedeniyle artık rekabet tamamen uluslararası alana kaymıştır. Bu nedenle işletmelerin yönetim ve organizasyonunun doğru şekilde idaresinde liderlik hayati önem taşımaktadır (Uğurluoğlu ve Çelik, 2009).

\subsection{Liderlik Türleri}

Liderlik konusunda literatürdeki çalışmalar incelendiğinde, yönetimsel olarak geleneksel liderliği oluşturan otokratik, demokratik ve tam 
serbesti tanıyan liderlik türleri ve çağdaş liderliliği oluşturan karizmatik, dönüşümcü ve etkileşimci liderlik tarzı olarak guruplandırıldığı görülmektedir.

Otokratik Lider: Yönetim açısından en eski liderlik türü olmasına rağmen günümüzde bile sıklıkla başvurulan bir liderlik tarzıdır. Bu tip liderlik tarzında lider, tek başına karar alan ve yöneten kişidir. Otokratik lider yetkisini devretmez ve paylaşmaz. Genellikle geleneksel yapıya bağlı ve yönetiminde sert kuralların bulunduğu toplumlarda grup üyelerinin bu tip liderlere büyük güven duyması, karar almada hızı ve uygulamada etkili bir tarz olması bu liderliğin yararları arasındadır. Ancak bunu yanı sıra otokratik liderlikte tek söz sahibinin lider olması, demoratik uygulamaların bulunmaması ve grup üyelerinin motivasyonları üzerinde ciddi olumsuz etkileride söz konusudur (Bakan ve Büyükbeşe, 2010).

Demokratik Liderlik: Liderlikte demokratik tarzı benimseyenler tutum, davranış ve eylemlerde tek karar alma mekanizması gibi davranmazlar. Alınması gereken kararlar gruplar ile paylaşılır, tartışılar ve bu şekilde amaca hizmet edecek en iyi yola ulaşılması hedeflenir. Lider, çalışanlarına yapılacak işler hakkında bilgi verip, verimli ve başarılı bir sonuç için sunacakları fikirlere önem verir. Demokratik liderlikte başarı için insan ilişkileri konusunda başarılı olmak en önemli unsurlardan birisidir (Stoner ve Edward, 1992).

Tam Serbestlik Tanıyan Liderlik: Liberal liderlik olarakta nitelendirlen Tam Serbestlik Tanıyan liderlerlik türünde liderler, kendileri tarafından kullanması gereken yönetim gücünü kişisel özellikleri nedeniyle kullanmaktan kaçınırlar. Liderin burada sahip olduğu yetkiyi çalışanlara dağıtarak sorumluluk almaktan kaçmaktadırlar. Çalışanlar yapacakları işlerde kendi başlarına yöntem ve yollar geliştirirerek bu şekilde amaçlara ulaşması hedeflenmiştir. Liberal liderler çalışanların yol göstericisi ve motivasyon kaynağı olmadığı gibi her bir çalışan kendisine sunulan imkanlar dahilinde kendi kişisel gelişimini sağlar, plan ve programlarını yaparlar. Liberal liderlerin ana görevi çalışanlar için gerekli kaynakları temin etmek ve bu konudaki sorunları çözmektir (Sabuncuoğlu ve Tüz, 2008). 
Karizmatik Liderlik: Antik çağlara kadar uzanan karizmatiklik sıfatı özellikle 80'li y1llardan sonra yönetim dünyasında önem kazanmaya başlamıştır. Toplumları derinden etkileyen büyük olayları yöneten ve idare eden kişiler genellikle karizmatik lider olarak nitelendirilmektedir. Karizmatik liderlerin gruplar üzerinde etkileyici ve sürükleyici tesiri bulunmaktadır. Aynı şekilde gruplarında karizmatik liderlere büyük bir güven duygusu ile bağl1lı̆̆ı söz konusudur. Karizmatik liderler başarı için izleyicilerine vizyonun önemini kavratarak örgüt hedeflerini gerçekleştirmeyi amaçlarlar (Özkaya, 2000).

Dönüşümcü ve Etkileşimci Liderlik: Etkileşimci liderlik tarzı geleneksel yapıya bağlı olan, işletmeler misyon hedeflerine ulaşmak için çalışanlarının ihtiyaçlarını en iyi şakilde karşılamaya ve bu şekilde motivasyonlarını yükselterek örgütsel hedefelere ulaşmayı amaçlayan bir tarzıdır. Bu tarz liderlikte genellikle çalışanların sıradan faaliyetlerinin en iyi ve en doğru şekilde gerçekleştirilmelerini sağlamak amaçlanmaktadır. Dönüşümcü tarzdaki liderler ise yeni fikirlere ve reformlara açı, özgün çalışma ve kişisel gelişimi destekleyen bir yapıdadırlar. Dönüşümcü liderler izleyicileri üzerinde doğrudan etkiye sahip olan, onların inançlarını ve sahip oldukları değerlerini değiştirebilen kişilerdir (Bakan ve Büyükbeşe, 2010).

\section{2. İnovasyon}

Latince "innovare" kelimesinden türetilmiş olan inovasyon, anlam olarak ortaya yeni bir şey çıkartılması veya mevcut yapısında önemli değişiklikler yapılması durumudur. Kavramsal olarak inovasyonu ilk kullanan ve girişimcilik konusunda olduğu gibi inovasyonu kuramsal yapısını çizen kişi ekonomist Schumpeterdir. Schumpeter işletmelerin ekonomik olarak kalkınması için teknolojiyle gelişen yeni üretim teknik ve süreçlerinin kullanılarak, yani inovasyon yoluyla başarılabileceğini belirtmiştir (OECD, 2005). Dünyada hızla değişen ve gelişen rekabet sürecinde işletmelerin tutunabilmesi için üretim süreç ve yöntemlerini, ürünlerinin niteliklerini ve sundukları hizmetleri inovasyonla devamlı olarak değiştirmeleri ve yenilemeleri gerekmekte olup, bu süreçlerin bütünü "inovasyon" olarak adlandırılır. Kısacası inovasyon, tüm alanları kapsaycak 
şekilde ve ticari amaç doğrultusunda gerçekleştirilen her türlü bilimsel araştırma ve icatlardır (Kamien ve Schwartz, 1982).

Her şeyden önce inovasyon bir ekonomik süreçtir. İşletmeler yoğun rekabetin yaşandığı pazarda varlıklarını sürdürmek ve kendilerine avantaj sağlamak için ortaya koyacakları ürünlerde yeni üretim teknikleri ve süreçlerini uygulamak zorundadırlar. Bunun için örgütlerin sektörlerindeki değişme ve gelişmeleri yakından izlenmesi, alanlarına ilişkin teknolojiye ayak uydurmaları gerekmektedir. Günümüzde bilim ve teknoloji dünyası, ekonomik kalkınmanın sağlanması ve yasam kalitesinin artmasının inovasyon sayesinde gerçekleşeceğini düşünmektedir (Oerlemans ve diğerleri, 2001).

İnovasyonda tesadüf ve şans faktörü bulunmaz. Faaliyetin sonunda ortaya bir ürün, bir hizmet veya çok farklı bir yönetim modeli de çıkabilir. İnovasyon için öncelikle o alanda istenilen bilgi birikiminin sağlanmış olması gereklidir. Araştırma geliştirme faaliyetleri ile inovasyon faaliyetleri nitelik ve bağlantı olarak birbirlerinin tamamlayıcısı olsalar da, olumlu sonuçlanan her araştırma inovasyona olarak değerlendirilemez. Ayrıca her inovasyon sonucu yenilik olarak ortaya çıkmayabilir. Ürün ve hizmetlerde köklü değişimlerde inovasyonun bir parçasıdır. Bu nedenle inovasyon, sadece yenilik olarak tanımlamak doğru olmayacağı gibi güncel teknoloji ve bilgilerin uygulanış süreci olarak nitelendirilebilir (Vatan ve Zengin, 2014).

Literatürde en fazla değinilen dört inovasyon çeşidi bulunmaktadır. Bunlar hizmet/ürün inovasyonu, süreç inovasyonu, pazarlama inovasyonu ve organizasyonel (örgüt) inovasyondur. Ürün/hizmet inovasyonu, yeni veya kullanım amaçları bakımından önemli oranda geliştirilerek yenilenmiş bir mal ya da hizmetin pazara sunulmasıdır. Süreç inovasyonu, mevcut ürünleri daha ucuza ve daha kaliteli olarak üreterek, dağıtım organları sayesinde etkin ve verimli şekilde pazara sunma yöntemleri geliştirip; maliyeti düşürme, performansı artırma ve teslimat konusunda sürecin iyileştirilmesi konularını kapsamaktadır. Pazarlama inovasyonu, ürünlerin tasarımı ve ambalajlanması, fiyatlandırılması, konumlandırılması ya da tutundurulmasında yapılan önemli değişiklikleri kapsayan bir pazarlama tekniğidir. Organizasyonel inovasyon, iş yapılarının, modellerinin ve uygulamalarının yeniden düzenlenmesini ve uyarlanmasını 
kapsamaktadır. Bu yüzden de; süreç, pazarlama ve iş modeli inovasyonlarını içine almaktadır (Ödemiş vd., 2017).

Tablo 1. Inovasyon Türleri

\begin{tabular}{ll}
\hline \hline \multirow{2}{*}{ Ürün İnovasyonu } & $\begin{array}{l}\text { Ürün inovasyonu; farklı ve yeni bir ürünün geliştiril- } \\
\text { mesi; ya da var olan üründe değişiklik yapılması ve bu } \\
\text { ürünün pazara sunulmasıdır. }\end{array}$ \\
\hline Hizmet İnovasyonu & $\begin{array}{l}\text { Bir işletmenin yeni, farklı ve değişik bir hizmet geliştirip } \\
\text { bunu müşterilerine sunmasıdır. }\end{array}$ \\
\hline Süreç inovasyonu, mevcut ürün veya hizmeti daha iyi ve \\
ucuz üretim ve dağıtım faaliyetleri ile verimli ve etkin \\
şekilde piyasaya sunma yöntemleri geliştirerek, perfor- \\
mansı artırma, maliyeti azaltma, hızlı ve doğru teslimat \\
konularında süreçlerin iyileştirilmesini kapsar.
\end{tabular}

Kaynak: Coşkun vd.,2013.

Yeni dünya düzeninde inovasyonel yaklaşımlar, işletmelerin rakiplerine göre rekabet üstünlügü yakalamasında oldukça önemlidir. Ancak söz konusu rekabet üstünlüğünün yakalanabilmesi için işletmelerin AR-GE çalışmaları, üretim ve bilgi teknolojileri ile yeni yönetim tekniklerinden en iyi şekilde faydalanmaları gereklidir. Bu nedenle İşletmelerin rakiplerine tam olarak üstünlük sağlamalarında bu yeni yöntemler ile etkin sonuçlar alabilirler ve öne geçebilmektedirler (Işık ve Serçeoğlu, 2015).

\section{Turizm Sektörü ve Genç Lider Yöneticilerin İnovasyon Anlayışı}

Artık her sektörde olduğu gibi hizmet sektöründe de artan rekabet ortamı, turizm alanında faaliyet gösteren işletmeleri, tüketicileri cezbedecek, onların istek ve ihtiyaçlarını en iyi şekilde karşılayacak ürünleri bulmaya sevk etmektedir. Turizm işletmelerinin bunu gerçekleştirebilmesinin yolu 
inovasyondan geçmektedir. İnovasyon sayesinde işletmeler, sürdürülebilir rekabet üstünlüğü elde ederek var olan müşterilerini koruduğu gibi rakiplerinden yeni müşteriler kazanmakta ve karlılığını artırarak performansını yükseltmektedirler (Tajeddini, 2011).

Dönmez ve Çevik'e (2010) göre rekabetin en yoğun yaşandığ hizmet sektörlerinden birisi olan turizm piyasasında tutununabilmek için yeni ürün ve fikirlerin ortay konulması gerekmektedir. Vatan'a (2010) göre turizmde inovasyon, işletmelerin ürün çeşitlendirmesi yoluyla yeni pazarlara yeni hizmetler ile girilmesi ve neticesinde daha fazla müşteriye hitap edilerek yüksek gelirler elde edilmesini sağlamaktadır. Baglieri ve Consoli'ye (2009); turizm sektöründeki inovasyon üzerinde müşterilerin etkisine dikkat çekmekte ve onları turizm inovasyonunun başarı sağlamasinda motivasyon gücü olarak görmektedir. Bu nedenle turizm işletmeleri başarıları için, "eğlence", "eğitim", "estetik" ve "romantik" konulu inovasyonu uygulamalarına dikkat etmelidir. Çamlı'ya (2010) ve Weiermair'e (2004) göre de turizm inovasyonunun ana faktörlerini oluşturan arz, talep ve rekabet ortamı, birbirinden bağımsız değillerdir ve inovasyonu birlikte etkilemektedirler (Coşkun vd, 2013).

Durna ve Babür (2011), ekonomik ve sosyal faydaları nedeniyle dünyada turizm sektörüne olan ilginin arttı̆̆ını bu yüzden sektörde faaliyet gösteren konaklama işletmelerinin sayısının da sürekli olarak arttığını belirtmişlerdir. Ancak artan işletme sayısının beraberinde getirdiği yoğun rekabette avantaj üstünlüğü sağlamak için müşteri istek ve ihtiyaçları doğrultusunda yeni ve farklı ürünler sunabilen, teknolojik gelişmelere ayak uydurulabilen, çevrenin korunmasında gerekli hassasiyeti gösteren yani diğer işletmelere göre kendisini farklılaştıran işletmeler ayakta durabileceklerdir. Bu yüzden otel işletmelerinin kendilerini geliştirebilmelerinin en iyi yolu inovasyon olarak gösterilebilir. Durna ve Babür'ün (2011) yaptıkları araştırmaya göre, konaklama işletmeleri gelecekleri açısından zorunlu olan değişim ve gelişim için sık sık inovasyon yapmaktadırlar. söz konusu işletmelerin genel olarak artımsal inovasyon boyutunun kapsadığı ürün, hizmet ve süreç inovasyonlarını uygulandıkları görülmüştür. Bunun yanı sıra, maliyet liderliği , farklılaştırma ve odaklanma stratejileri ile atılga ve fırsatçı inovasyon stratejisi arasında pozitif yönlü bir ilişki olduğu bulunmuştur ( Coşkun vd, 2013). 
Sıklıkla da ifade edildiği üzere, küreselleşmenin ortadan kaldırdığı ticari sınırlar işletmelerin varlıklarını sürdürebilmelerini daha güç hale getirmiştir. Bu nedenle işletmelerin tüm dünyadaki en son tekonolojik trendlere ayak uydurabilmeleri, müşterilerinin istekleri doğrultusunda farklı ürünler tasarlamaları ve paydaşlar ile ilişkilerini daha uzun süre devam ettirebilmeleri için inovasyona ihtiyaçları vardır. Ancak başarılı bir inovasyo için ilk şartı iyi bir yöneyim ve liderdir. İnovasyon faaliyetleri yapısı gereği her aşamasında problemlerin ortaya çıtı̆̆ı, karmaşık ve sorunlu bir süreci vardır. Bu zorlu süreçlerden başarılı bir şekilde çıkılması ise şüphesiz iyi bir lider ile mümkün olabilmektedir (Barker, 2001).

Yeniliğe açık olan turizm işletmelerindeki genç lider yöneticilerin bulundukları işletmeyi sektörün en iyileri statüsüne getirdikleri herkes tarafından kabullenilen bir durumdur. Turizm sektörü açısından baktığımızda bu alanda yatırım yapanların sektörü yönlendirdiği ve değişimi çabuk isteyen hizmet sektörü müşterilerinin isteklerine en iyi cevabı bu işletmelerin vermesi düşünülmektedir. Bundan dolayıdır ki işletmedeki genç lider yöneticilerin anlayış olarak kabulleneceği liderlik türü davranışları inovatif eğilimlerinde önemli bir rol oynamaktadır.

\section{Sonuç}

İnovasyon konusunda bugüne kadar yapılan tüm araştırmalar göstermektedir ki işletme başarısı ve sürekliliği için inovasyon hayati önem taşıyan bir gerekliliktir. Günümüzde küreselleşmenin bir sonucunda olarak çeşitlenen ve değişen pazar yapısı, artan nüfusla birlikte müşteri ihtiyaçlarındaki doyumsuzluk ve tüketim çılgınlığı karşısındaki talebin karşılanabilmesi, ancak işletmelerin rekabetçi yapılarını koruyabilmeleri ve sürdürülebilir inovasyon faaliyetlerini hayata geçirmeleri ile mümkündür. Bu yüzden inovasyon, işletmelerin yaşamlarını sürdürmelerindeki en önemli faktörlerden birisi olurken, diğer taraftan sürekli artan tüketim ihtiyacını da karşılayarak tüketicilere de hizmet etmektedir.

Hiç şüphesiz inovasyona konu olan sektörlerin başında bir hizmet sektörü olan turizm gelmektedir. Turizm faaliyetleri, konu ve yapı olarak bir hizmet sektörü gibi gözükse de, söz konusu faaliyetlerin katma değer etkisi ekonomik olarak tarım, ulaşım, gıda ve inşaata gibi altmışa yakın sektörü doğrudan etkilemektedir. Ayrıca turizmin ülkelerin ödemeler 
bilançosu, milli gelir ve istihdam politikaları üzerinde ciddi anlamda katkısı bulunmaktadır. Bu nedenle turizm işletmeleri daha fazla müşteri çekebilmek için onların istek ve ihtiyaçları doğrultusunda yeni ürünler tasarlayarak veya mevcut turistik ürün ve hizmetlerde değişim yaparak inovasyon yapmaktadırlar. Özellikle gelişmiş ülkelerde yürütülen turizm faaliyetlerinde inovasyon merkezli strateji ve politikalar geliştirme çalışmalara önem vererek çalışmalarını sürdürmektedirler.

İnovasyon'un başarıya ulaşması için teknolojinin, pazarlama süreçlerinin, insan kaynaklarının ve organizasyon yapısının en iyi şekilde organize edilmesi ve yönetilmesi gerekmektedir. Bu nedenle inovasyon başarısındaki en büyük görev yöneticilere düşmekte olup, iyi bir yönetici olmak için öncelikle de iyi bir lider olmak gerekmektedir. Literatürde, inovasyon lider ilişkisi incelendiğinde liderlik özelliğine sahip örgüt yöneticilerinin inovasyona daha yatkın oldukları ve genellikle kendilerine tanımlanan liderlik türüne göre inovasyon algısı içerisinde oldukları görülmektedir. Günümüzün bilgi çağ1 olduğu düşünüldüğünde iyi eğitim almış, alanında her türlü teknolojiyi en iyi şekilde kullanabilecek kapasiteye sahip genç liderlerin önemi giderek artmaktadır.

Literatürdeki araştırma sonuçlarından geleneksel olarak nitelendirilen liderlerin öngörü ve tecrübesinin daha yüksek olduğu ancak buna rağmen yenilik ve değişim konularına kapalı oldukları, Oysa çağdaş tarzda yönetim anlayışına yönelen günümüzün genç liderleri yeni fikirler bulmak, üretmek ve uygulamak konularında daha istekli oldukları sonucuna varılmaktadır. Sektörlerinde dünyanın en büyükleri olan Apple ve Microsoftun kurulması ve başlangicında doğru şekilde yönetilerek günümüzde dünya devine dönüşmeleri iyi bir genç lider örneği olarak nitelendirilebilir. Sonuç olarak rekabetin gitgide daha da kızıştığı bir ortamda işletmelerin varlıklarını sürdürebilmeleri ve daha iyi bir pazar payı elde edebilmeleri için, inovasyona açık, alanında iyi eğitim almış ütopik olmayan hayal gücüne ve girişimci ruha sahip, yenilikten ve denemekten korkmayan genç liderler yetiştirmesinin ve onlara yönelmesinin doğru bir tercih olacaktır. 


\section{Kaynakça}

Baglieri, D. ve Consoli, R. (2009). Collaborative innovation in tourism: Managing virtual communities. The TQM Journal, 21(4), 353-364.

Bakan İ. ve Büyükbeşe. T. (2010). Liderlik türleri ve güç kaynaklarına ilişkin mevcut-gelecek durum karşılaştırması: Eğitim kurumu yöneticilerinin algılarına dayalı bir alan araştırması, KMÜ Sosyal ve Ekonomik Araştırmalar Dergïi, 12(19), 73-84.

Barker, A. (2001), Yenilikçiliğin simyası. Çeviren: Ahmet Kardam, Yayın No: 391, İstanbul:, Mess Yayınları, 89-90.

Cohen. W. A. (2010). Drucker ve liderlik, İstanbul: Optimist Yayınları.

Coşkun. S. Mesci. M. ve Kılınç. İ. (2013). Stratejik rekabet üstünlüğü sağlama aracı olarak inovasyon stratejileri: Kocaeli otel işletmeleri üzerine bir araştırma, AİB̈̈ Sosyal Bilimler Enstitüsü Dergisi, 13(2). 101-132.

Çaml, U. (2010). Yeniliğin müssteri sadakati üzerine etkileri; turizm sektörüne yönelik bir araştırma. Ankara Üniversitesi, Sosyal Bilimler Enstitüsü, Yayınlanmamış Yüksek Lisans Tezi, Ankara.

Dönmez, D. ve Çevik, İ. (2010). İşletmelerde yeniliklerin kaynağı olarak paydaş diyalogları: seyahat acenteleri üzerine nitel bir araştırma. Selçuk Üniversitesi, Sosyal Bilimler Enstitüsü Dergisi, 24, 189-202.

Durna, U. ve Babür, S. (2011). Otel işletmelerinde yenilik uygulamaları. Uluslararası Alanya İsletme Fakültesi Dergisi, 3(1). 73-98

Işık. C. ve Serçeoğlu N. (2015). İnovasyonel turizm: Çin örneği, Bingöl Üniversitesi Sosyal Bilimler Enstitüsü Dergisi, 5(9), 1-15.

İbicioğlu. H. Özmen. İ. ve Taş. S. (2009). Liderlik davranışı ve toplumsal norm ilişkisi: Ampirik bir çalışma, Süleyman Demirel Üniversitesi İktisadi ve İdari Bilimler Fakültesi Dergisi 14(2), 1-23.

Kamien. M. I.. ve Schwartz. N. L. (1982). Market structure and innovation, Cambridge University Press. 12. Cambridge.

Kuzey Anadolu Kalkınma Ajansı (KUDAK) (2011). 2012-2023 İnovasyona dayalı turizm stratejisi ve eylem planı.

Mehmet. H. A. ve Sezerel. H. (2015). Öykünme ve özgünlük: Turizm alanındaki liderlik araştırmaları üzerine eleştirel bir inceleme. $\mathrm{Hi}$ tit Üniversitesi. Sosyal Bilimler Enstitüsü Dergisi. 8(2), 715-732. 
OECD ve Eurostat (2005). Oslo klavuzu: Yenilik verilerinin toplanması ve yorumlanmast için ilkeler. 3. Baskı, OECD-Eurostat Ortak Yayımı.

Oerlemans, L.A.G. Buys, A. J. ve Pretorius, M. W. (2001), Research design for the South African innovation survey. Working Paper 01.02, The Netherlands: Eindhoven Centre for Innovation Studies.

Ödemiş. M. Düzgün. E. ve Düzgün A. (2017). Turizm destinasyonlarının rekabet gücünü artırmasında inovasyonun yeri. Uluslararası Bilimsel Araştırmalar Dergisi, 2(4), 22-29.

Özkaya. O. M. (2000). Bir lider olarak Vehbi Koç, Adnan Menderes Üniversitesi, Aydın: Basılmamış Doktora Tezi.

Sabuncuoglu. Z. ve Tüz. M. (1998). Örgütsel psikoloji. Bursa: Alfa Basım,Yayım ve Dağıtım A.Ş.

Stoner, J.A. ve Edward. F.R. Management. Prentice Hall; New Jersey. 1992.

Şahin, Ali, Temizel, H., Örselli, E., ( 2004), Bankacılık sektöründe çalışan yöneticilerin kendi liderlik tarzlarmı algılayıs biçimleri ile çalı̧̧anların yöneticilerinin liderlik tarzların algılayıs biçimlerine yönelik uygulamalı bir çalışma.3. Ulusal Bilgi, Ekonomi ve Yönetim Kongresi Bildiri Kitabı, Sözkesen Matbaacılık, Eskişehir, 657-665.

Şimşek. Ş.M. ve Çelik. A.(2011). İşletme yönetimi, İstanbul: Eğitim Yayınevi. Tajeddini. K. (2011). The effects of innovativeness on effectiveness and efficiency: Education, business and society. Contemporary Middle Eastern Issues, 4(1), 6-18.

Taşgit. E.S. ve Torun. B. (2016). Yöneticilerin inovasyon algısı, inovasyon sürecini yönetme tarzı ve işletmelerin inovasyon performansı arasındaki ilişkiler: KOBİ'ler üzerinde bir araştırma. Yönetim Bilimleri Dergisi, 14(28), 121-156.

Taşkıran E. (2006). Otel işletmelerinde çalışan yöneticilerin liderlik yönelimleri: İstanbul' daki beş yıldızlı otel işletmelerinde bir araştırma. Anatolia: Turizm Araştırmaları Dergisi, 17(2), 169-183.

Uğurluoğlu Ö. ve Çelik Y. (2009). Örgütlerde stratejik liderlik ve özellikleri, Hacettepe Sağlık İdaresi Dergisi, 12(2), 122-156.

Vatan A. ve Zengin B. (2014). Çevresel inovasyon ve konaklama işletmelerindeki uygulamalar üzerine bir araştırma: İstanbul örneği. $A k a-$ demik Sosyal Araştırmalar Dergisi, 2(8), 511-530. 
Vatan, A. (2010). Turizm işletmelerinde inovasyon: İstanbul'daki beş yıldızlı konaklama işletmelerinde bir araştırma. Balıkesir Üniversitesi, Sosyal Bilimler Enstitüsü. Yayınlanmamış Yüksek Lisans Tezi, Balıkesir.

Werner, I. (1993). Leadership skills for executives, Çeviren: Vedat Üner, Liderlik ve Yönetim. Kişisel Gelişim ve Yönetim Dizisi 1. İstanbul: Rota Yayınları.

Kaynakça Bilgisi / Citation Information

Türk, M. ve Kara, E. (2018). Genç lider yöneticilerin inovasyon anlayışı: Turizm sektörü üzerine bir alan araştırması. OPUS - Uluslararası Toplum Araştırmaları Dergisi, 8(Gençlik Araştırmaları Özel Sayısı), 108-124. 